\title{
Research on Difficulties and Innovation of Rural Finance in Underdeveloped Area
}

\author{
$\mathrm{Ke} \mathrm{Lu}$ \\ Wuhan University of Science and Technology \\ Wuhan, China, 430065
}

\author{
Dan Liu \\ Wuhan University of Science and Technology \\ Wuhan, China, 430065
}

\author{
Yan Pei \\ Wuhan University of Science and Technology \\ Wuhan, China, 430065
}

\begin{abstract}
The structural reforms of agriculture and rural areas are always the focus of Chinese government to implement public management activities. In order to reasonably and orderly operate the capitals that have been introduced into the field of agriculture, farmer and rural areas, our government needs the help of the platform of rural finance. This article analyzes the current situation of rural financial organization in underdeveloped areas and tries to find problems existed in rural financial system in underdeveloped areas of our country. According to the focus of rural financial reform in underdeveloped areas and fundamental policies of rural financial reforms in our country, it provides feasible suggestions for the improvement of rural financial system in underdeveloped areas and puts forward selection and analysis of innovative strategy of rural finance. In addition, it analyzes the condition of rural finance in underdeveloped area and regards economical and practical type of rural labor force from the perspective of finance and puts forward the pattern of innovation.
\end{abstract}

Keywords - rural economy in underdeveloped areas; financial innovation; rural financial system

\section{INTRODUCTION}

Underdeveloped areas mainly refer to the areas that have certain economic strength and development potential but the levels of productive forces and science and technology are relatively backward, the degree of industrialization is low and there are still very big disparities between some developed areas and them. Compared with developed areas, the rural economic development of underdeveloped areas is relatively backward and the income level of peasant household is also lower. It is difficult for peasant households in these areas to accumulate capitals to expand the scale of agricultural production. It is extremely difficult for them to undertake the innovation of peasant household production or higher level of non-agricultural economy. At present, in some areas with severe backward economy, because peasant households have limited income level, it is impossible to guarantee the basic life level of them. Therefore, it will become the key for the transition of rural economy in underdeveloped areas to actively reform the industrial structure of rural economy and improve the establishment of rural financial system in underdeveloped areas.

\section{CURRENT SITUATION OF RURAL FINANCIAL SUPPLY SYSTEM}

After years of exploration, the construction of rural financial system in China makes progress continuously and gets great development and improvement. Financial products are enriched and renovated constantly, financial services are improved and financial mode is renovated. But the rural financial supply market in underdeveloped areas still cannot meet the practical needs of rural development in our country. There are still many problems remained to be solved. Energetically developing "agriculture, farmer ad rural area" is the guarantee for the stable and sustainable development of rural economy in our country and it is also the focus to realize the well-off objective in rural areas. The rural economic development in underdeveloped areas cannot do without the strong support of financial institutions. Because rural industrial management has characteristics of "low effectiveness and risk" , most of commercial banks are unwilling to provide financial services for rural areas. It leads to the situation that the finance industry in rural areas develops slowly and the capital investment is severely inadequate.

\section{A. The Existing Financial Organization in Rural Areas Is Imperfect}

Because formal rural financial organizations in underdeveloped areas are imperfect, it cannot provide enough financial services. In reality, it is the main channel of capital outflow in rural areas. This organizational form seriously breaks the balance of supply and demand system of rural finance.

The investment environment in rural areas is not good and the cost and risk are high if financial institutions invest in agriculture, farmer and rural area. Meanwhile, financial institutions transfer financial resources to non-farming departments and cities with high profits and low risks through ways of capital outflow, credit and loan and buying national debt. 


\section{B. The Ways of Rural Financial Service Are Inadequate}

In vast market towns in rural areas, there are few financial institutions outlets. Take the nationally designated poor county of Macheng in Hubei province as an example. There are only 75 outlets in 16 towns. Each town has 4.6 outlets on average. With the improvement of rural industrialization and marketization, rural areas have more demands for financial services. Most of rural financial institutions have low rights in networking. The use of Union Pay card is restricted and the procedure of capital settlement is complex. Under the condition of electronic information networking, some banks of agriculture and commerce have not open systems for large payment and cannot realize universal cash saving and withdrawing.

\section{Financial Products in Rural Areas Are Single}

Financial products in rural areas are single. Most of them are short-term and petty credit mortgage loans. It lacks customized products for rural economic organizations such as large scale contract farmers of farmlands and growing township enterprises. The matched-degree of rural financial products and actual demands is low. The single products of rural credit cannot conform to diversified demands in rural areas. It is difficult for old service and marketing mode to meet the requirements of the development of rural economy. It is urgent for rural financial institutions to practically and effectively speed up the innovation of credit products in rural areas to develop business. Take Chenzhou in Hunan province as an example. It is the trial city of innovation of agricultural financial products. There are few innovative products. New products come to a premature end because the implementation of marketing and relevant matched works does not reach the designated position. In the 20 kinds of innovative products of agriculture-related loans, there are no products related to consumption. The loans less than 5,000 yuan accounts for 83.55 percent of peasant household loan. The short-term loan accounts for above 82 percent. The small loan commitment with short term is not consistent with actual demands.

\section{REASONS ANALYSIS}

\section{A. Inadequate Government Support}

At present, the rural financial service network in underdeveloped areas of our country has not formed. The encouragement policies of government for various banks such as rural credit cooperative, postal savings and village banks are inadequate. The development of "agriculture, farmer and rural area" that urgently needs the support of government policies is also relatively backward. The absence of fiscal taxation policy that serves as joint policy of financial and monetary policy is also one of the reasons. In market competition, because of the weak position, it needs policies to supplement and provide tax preference to support. The systems of supporting policies of finance and fiscal levy that support the development of agricultural industry are also not sound. The confirmation of land right and land circulation in rural land circulation system is still at preliminary stage of practice.

\section{B. Backward Financial System Reform}

At present, underdeveloped areas in our country have relatively low ability in withstanding the violation of force majeure such as natural disasters. The economic losses such as reduction in grain yield brought by natural disasters for the farmers in underdeveloped areas are still relatively large. It seems even more important to reform and develop rural financial institutions that specifically help farmers to reduce agricultural losses and guarantee agricultural economical development. Underdeveloped areas in our country have not set up a special financial institution to provide insurance of agricultural economical development. Problems of agricultural insurance are remained to be solved.

\section{The Core of Financial Industry Is Mainly in Cities}

At present, most of financial systems in our country focus on large and medium-sized cities, while the channels of rural financial organizations in underdeveloped areas have not been fully developed. Because the purchasing power of farmers in these areas is relatively low and the development of rural finance is slow, most of farmers cannot participate in rural financial insurance and the government has not set up corresponding subsidy policies of agriculture-related insurance. Farmers who desire to by agricultural insurance have to step back in front of the huge payment of commercial insurance. The reasons at deeper levels are that the financial ecological environment in underdeveloped areas is not good and the level of financial thought consciousness of farmers is low. The imperfection of rural financial system greatly combats the enthusiasm of farmers to participate in agricultural development. In the face of huge risks of agricultural development, the strength of agricultural capital is also faced with challenges. Financial capitals in rural areas are also seriously inadequate.

\section{INNOVATIVE STRATEGY OF RURAL FINANCIAL SUPPLY SYSTEM}

With the development of rural economy, rural finance presents new characteristics. In order to better adapt to the demands of rural finance, it is necessary to renovate the existing rural financial system.

\section{A. Strengthen the Responsibility of Financial Institutions to Serve "Agriculture, Farmer and Rural Area"}

On the main aspect that financial institutions serve "agriculture, farmer and rural area", the government should make efforts to dredge the channels of financial service, perfect the financial service network, formulate various preferential policies, encourage all kinds of banks to go into underdeveloped areas and expand the construction of financial services in underdeveloped areas. Except for banking system, some rural financial support organizations or small guarantee corporations can also actively participate in the construction of "agriculture, farmer and rural area" after getting the permission of policies. Strengthen the responsibilities of rural finance, bring in a large number of development funds for the agricultural development of underdeveloped areas and truly realize the service mechanism of "giving more and taking less" of our country. 


\section{B. Develop New Type of Rural Cooperative Financial Organization}

On the basis of peasants' cooperative and supply and marketing cooperatives with democratic management, standard operation and strong driving force, cultivate and develop rural cooperative finance and continuously enrich the type of financial institutions in rural areas. Insist the commune member system and closure principle, under the condition of not absorbing savings and lending externally and not paying fixed returns, promote the development of rural capital cooperative organization with community character. Improve local rural financial management system and determine the regulatory functions of local government for the new type of rural cooperative finance, encourage local governments to create risk compensation funds to effectively prevent financial risks, and formulate management methods for rural cooperative finance development in good time.

\section{Increase the Strength of Support of Agricultural Insurance}

At present, some underdeveloped areas in our country have not established corresponding insurance mechanism of agricultural economy. The government should timely formulate corresponding subsidies measures to help farmers who encounter force majeure of natural disasters and give corresponding compensation for the agricultural losses suffered by them. Establishing premium subsidy can effectively avoid financial losses of farmers and provide guarantee for the sustainable development of "agriculture, farmer and rural area" of our country.

The government should gradually establish policy-related agricultural insurance companies to go deep into the areas with few service network stations and inadequate service personnel. Through establishing agricultural insurance mechanism, disperse agricultural risks of farmers, reduce risks and eliminate agriculture-related risks. Through establishing financial mechanism of agriculture-related insurance, encourage farmers to participate in the insurance, implement agricultural insurance subsidies after getting the permission of finance, provide subsidies of fees for safety mechanism and reduce the pressure of farmers in buying agricultural insurance.

\section{INNOVATION OF RURAL FINANCIAL ORGANIZATIONS IN OUR COUNTRY - ESTABLISH MULTILEVEL RURAL FINANCIAL ORGANIZATION SYSTEM}

\section{A. At the Present Stage, There Are Many Financial Organizations with Different Properties and Scales in Rural Financial Systems in Our Country.}

The traditional rural grass-roots financial organizations include Postal Savings Bank of China, Agricultural Bank of China and rural commercial banks. In recent years, there are also some small and medium-sized commercial banks participate in rural finance. In rural areas, rural commercial banks hold the dominant position. They monopolize rural finance and restrict the play of financial service function. When increasing the capital investment into agriculture, farmer and rural area, it is also necessary to renovate the financial services in rural areas to realize effective allocation of capitals as well as commercialized operation.

1) The organization and operation innovation of rural commercial banks. Rural commercial banks occupy most of the rural financial market, but they also need to continue to deepen the reform. In terms of deposit taking, they should avoid the time of credit crisis appeared in its predecessor, namely the rural credit association, consider establishing and improving deposit insurance system to increase the credibility of the public, and know clearly about the property right structure. The state-owned equity capital accumulated by rural commercial banks can try the marketability operations such as entrusted operation and sale to increase the interest. They should change the original small shareholders cooperation mode into local joint stock cooperative system.

2) Know clearly about the market positioning of Agricultural Bank of China. As the solely state-owned commercial bank, its financial features embody in two positioning of rural commercial finance and policy based finance. In order to comply with the requirements of economic development, as one of the four state-owned commercial banks, the Agricultural Bank of China changes its business function and it can more highlight the commercial financial characteristics and transfer the key emphasis in work to the city. Turn over the policy-based financial services in agriculture to Agricultural Development Bank, which is policy-based financial institution. Under the financial commercial positioning, realize the marketability operation, start from the perspective of interest to grasp the key customers. Although it separates from the policy-based positioning, depending on the close relationships with farmers, it can continue to give play to the advantages of some grassroots outlets to promote businesses for customized products such as large-scale agricultural industrialization project and projects of construction of rural infrastructure, etc.

\section{B. Innovation of Rural Financial Service}

The theory of technology driving thinks that the convenient means and tools provided by modern science have promoted the innovation of financial services. The modern information and network technology established on the basis of electronic technique, communication technology and network technique has been applied to financial departments. It reduces the cost and transaction expenses. At present, rural finance in our country cannot well use the modern science and technology. It needs the help of modern network communications technology to promote the innovation in financial services to provide correct, rapid, convenient and considerate financial services for clients.

1) Improve the settlement services and promote the electronic banking business. Carrying out the innovation of settlement means can help to increase the efficiency of turnover of capitals in rural areas and provide flexible services for clients. Electronic bank is a kind of convenient and innovative settlement tool. The development of rural electronic bank is limited to the inconvenient network in rural areas. The government should increase the popularity of modern network in rural areas. 
2 ) Establish and improve the payment system in rural areas. Encourage and support the payment and settlement system and transaction processing system of rural financial institutions, develop and popularize products of payment and settlement services that suit rural areas. Increase the publicity and guidance, improve the card-using environment in rural areas and actively develop bank card business. In commercial and real estate development in underdeveloped areas, positively construct the range of application of Union Pay card and increase the amount of POS terminals machine.

3 ) Energetically develop intermediate business. Except for the convenient mode of payment and scientific payment system, rural financial organizations should positively develop intermediate business. At present, the development of intermediate business in rural financial market is relatively backward and it is at the initial stage basically. In terms of developing intermediate business, start from the present collecting of water and electricity and salary, base on the actual status of economic development in rural areas, and actively carry out businesses such as insurance agency and funds sale on a commission basis to increase the profit.

\section{Innovation of Rural Financial Products}

The main problem faced by rural areas is that it is difficult for agricultural projects to loan. In order to solve this problem, it is necessary for rural financial institutions to renovate financial products and use new operation mode. The central bank in our country actively supports and enlarges the credit and loan of "agriculture, farmer and rural area", steadily widens the range of application of reloading system for supporting peasants.

1 ) Fully develop the small fiduciary loans to the farmers. Looking from the present actual situation, rural financial institutions base on the construction of rural credit project, enlarge the coverage of loan through petty loan and at the same time train farmers into effective and stable client base with large market shares and low risks. Continue to base on the actual situation of service area of micro-credit, positively try various types of loan, develop and release other financial products such as funds, insurance and credit card, etc. Expand the channel of credit service and capital source to support the increase of the income of farmers and the benefit of their own.

2) Develop the loan for rural professional economic organization. At present, the division of labor in our country is further professionalized. The general agricultural trend gradually appears in rural areas. The rural professional economic organization has got rapid development. Developing financial products that suit the rural financial institutions has become the new point for rural finance to expand rural business. The new-type professional farmers' professional cooperative faces seasonal and temporary shortage of funds in the development and needs rural financial institutions to develop corresponding loan products. According to standardized degree and economic strength of rural specialized cooperative association, divide different credit rating to provide professional diversified loan products. For rural cooperative organizations with the property of legal person, develop mortgage type of high amount of loans; for collective of cooperative associations, develop order types of loan or the loan of collective joint guarantee; for individual peasants participating in the cooperation, develop the business of microcredit loans; for rich families of planting and cultivation with certain scale, properly take mortgage + petty loan to realize high amounts of loan to meet the requirements of reproduction. In improving the credit rating of peasant households, they can refer to model of loan of contract farming and enlarge the loans through the credit of party B (company +association +base +farmers). Establish and improve the credit evaluation system, develop and construct cooperative system of financial institutions to realize the united investment of financial institutions.

\section{CONCLUSION}

The establishment of rural financial system helps the settlement of the issue concerning "agriculture, farmer and rural area" and it is the important basic condition for building moderately prosperous society. It is a gradual process full of opportunities and challenges to reform and renovate rural financial system and improve the rural financial service. Therefore, in the innovation of rural financial supply system, it is necessary to be guided by the spirit related to rural financial reform in "No. 1 document" of central government in 2014, start from solving problems concerning agriculture, farmer and rural area, pay attention to the innovation of operation mode and the sustainable development of rural financial institutions and make efforts to improve the rural financial supply system, pay attention to the financialization of rural labor force and turn it into labor capital.

\section{REFERENCES}

[1] Wu Zhiyuan. Analysis on Effective Demands of Rural Finance in Underdeveloped Areas [J], Truth Seeking, 2010(1)

[2] Yan Changyuan. Research on Establishment and Development of Rural Financial System in Underdeveloped Areas [J], Agricultural Economy, 2012(5)

[3] Wei Yanyan. Analysis on Reform Problems of Rural Financial System in Underdeveloped Areas [J], West China Finance, 2013(11)

[4] Xu Dandan. Research on Influences of Rural Finance Development in China for Rural Economy [J], Economic Review, 2013(10)

[5] Li Yanting. Innovation on Social Capital and Rural Financial System [J], Gansu Social Sciences, 2013(5)

[6] Conning, J., 2005, "Monitoring by Delegates or by Peers Jointliability Loans under Moral Hazard", William College, Williamstown, MA 01267, USA 